\title{
Rancang Bangun Aplikasi Pencatatan Stok dan Penjualan UD Pawon Kue
}

Developing A Listing and Stock Application at Pawon Kue

\author{
${ }^{1}$ Indra Budi Trisno, ${ }^{2}$ Wiria Chandra \\ ${ }^{1,2}$ Teknik Informatika, ${ }^{1}$ Universitas Widya Kartika Surabaya \\ ${ }^{2}$ Institut Informatika Indonesia \\ ${ }^{1,2}$ Surabaya, Indonesia \\ E-mail: ${ }^{1}$ indrabt@gmail.com , ${ }^{2}$ wiriachandra@gmail.com
}

Abstrak-UD Pawon Kue adalah Usaha Kecil Menengah yang bergerak di bidang penjualan kue kering, basah dan nasi kotak. UD Pawon Kue melakukan pencatatan stok dan penjualan dengan menggunakan cara manual. Cara pencatatan ini menyebabkan UD Pawon Kue sering merasa kesulitan karena sulit untuk menentukan laba yang diperoleh, lama dalam mencari suatu informasi, dan kemungkinan hilangnya catatan yang dibuat. Penulis dan team mencoba membuatkan aplikasi berbasiskan web untuk membantu UD Pawon Kue dalam me lakukan pencatatan stok dan penjualan produk -produk. Pembuatan program menggunakan metode Waterfall dan untuk tahap desain dan analisa sistem menggunakan konsep Unified Modelling Language (UML). Hasil uji coba yang dilakukan software yang dilakukan oleh penulis dan team menunjukkan bahwa program dapat memudahkan UD Pawon Kue dalam melakukan pencatatan stok dan penjualan.

Kata Kunci-UD Pawon Kue, Penjualan produk, pencatatan produk

Abstract-Pawon Kue is a small home industry which sells various cake and rice box products. Pawon Kue was using books for recording orders and product selling. The method was used since the company established. However, the company experienced difficulities when using this method. The process to find how much the profit they got in a day was not easy, it also needed long time to find certain information, and there were big probability they could lose the recording books. Because of them, the author and the team developed a web based application for helping them in recording sales and stock listing. The team used waterfall model in software enginering model and used Unified Modeling Language in design and system analyst stage. After the testing stage, the research team found the application could help the owners for listing stock and product easier than before.

Keywords-Pawon Kue, Sales Listing, Product Listing 
INTENSIF, Vol.2 No.2 August 2018

ISSN: 2580-409X (Print) / 2549-6824 (Online)

Website: http//ojs.unpkediri.ac.id/index.php/intensif

\section{PENDAHULUAN}

Pada era globalisasi, tingkat persaingan pada bermacam-macam bidang seperti ekonomi, politik serta kehidupan sosial di masyarakat semakin tinggi, maka para pelaku usaha diharuskan untuk melakukan peningkatan atau inovasi pada sistem informasinya. Sistem Informasi juga merupakan salah satu bagian penting dari perusahaan. Penggunaan sistem informasi ini apabila diterapkan dalam perusahaan baik perusahaan kecil maupun perusahaan besar dapat meningkatkan produktifitas. Beberapa fungsi dari sistem informasi adalah memperoleh informasi secara cepat dan tepat [1], mengolah dan menggunakan informasi tersebut terutama untuk kepentingan intern perusahaan.

Perkembangan Teknologi Informasi dan Komunikasi merupakan satu hal yang tidak dapat dihindari oleh seluruh aspek kehidupan masyarakat. Saat ini Teknologi Informasi sudah banyak digunakan sebagai pendukung proses bisnis di berbagai instansi. Selama dua puluh tahun perubahan untuk implementasi Sistem Informasi dalam organisasi telah meningkat [2]. Modernisasi Teknologi Informasi dan Komunikasi sebagai pendukung proses bisnis juga berdampak pada kemajuan organisasi. Namun pada kenyataannya, implementasi dan pembaharuan Teknologi Informasi tidak berarti berlangsung tanpa masalah. Sayangnya, tidak semua perusahaan memahami peranan Teknologi Informasi yang diharapkan mendukung terciptanya peningkatan kinerja organisasi seringkali malah menjadi faktor penghambat dalam menjalankannya. Hal ini juga dirasakan oleh mitra penelitian yaitu UD Pawon Kue.

UD Pawon Kue merupakan UKM yang bergerak di bidang penjualan berbagai macam kue seperti kue kering, kue basah maupun nasi kotak. UD Pawon Kue ini didirikan pada tahun 2014 oleh Ibu Choirul Mahpuduah, dan beralamat di Kampung Kue Rungkut Lor II / 1 Surabaya 60293. Produk-produk yang dijual oleh UD Pawon Kue meliputi kue lapis, buku ayu, donat, lemper, onde-onde, kue sus, risoles, pie susu, lepet, klepon / kue yang dibuat sesuai dengan pesanan pembeli. Produk andalan UD Pawon Kue adalah Almond Crispy seperti yang ditunjukkan pada gambar 1. UD Pawon Kue dalam melakukan pencatatan stok dan penjualan masih belum terkomputerisasi, akibatnya nota-nota penjualan tidak tertata dengan rapi dan sulitnya dalam melakukan pengecekan stok yang telah ada. Permasalah lain yang terjadi adalah rendahnya control terhadap stok sehingga kualitas yang dimiliki kadang kurang terjaga karena belum adanya system inventory control yang baik. 


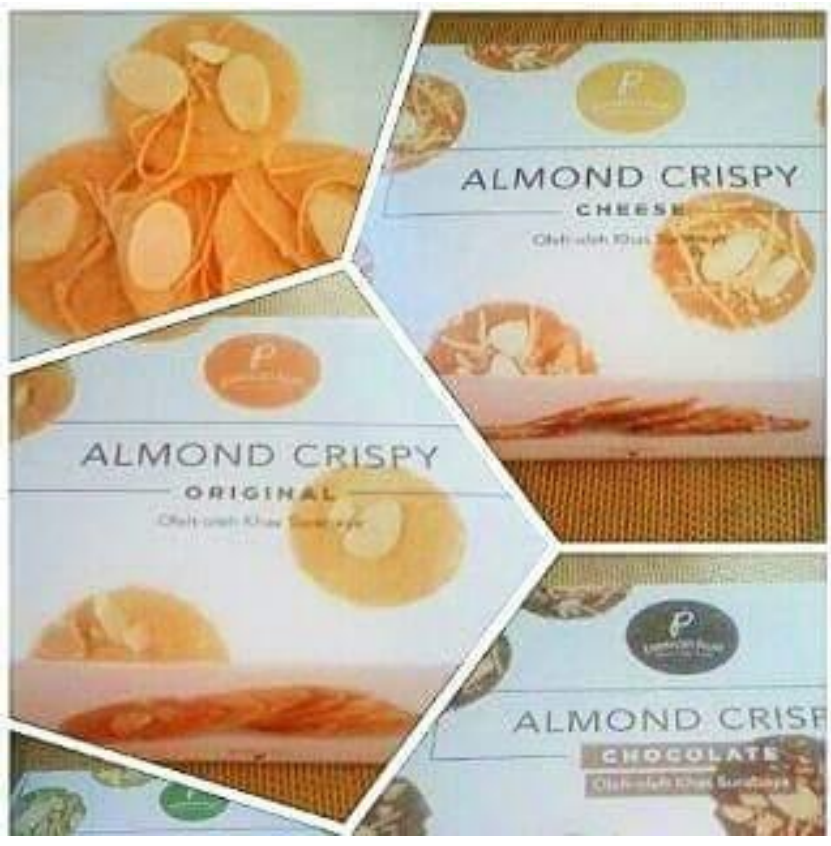

Gambar 1. PRODUK ALMOND CRISPY Ud PAWON KUE

\section{DASAR TEORI}

\section{Pe rancangan Sis tem Informasi}

Sistem Informasi merupakan suatu kesatuan yang terdiri dari berbagai macam komponen yang saling berhubungan untuk melakukan suatu fungsi tertentu dan pada akhirnya diharapkan fungsi tersebut dapat membawa perusahaan mencapai suatu tujuan tertentu [3] .Pengertian sistem informasi lainnya menurut Abdul Kadir [4] adalah "Sistem Informasi adalah kombinasi antara prosedur kerja, informasi, orang, dan Teknologi Informasi yang diorganisasikan untuk mencapai tujuan dalam sebuah organisasi." Pendapat lain menurut Bodwar dan Hopwood pada dalam buku Abdul Kadir Edisi Revisi menyatakan bahwa "Sistem Informasi adalah kumpulan perangkat keras dan perangkat lunak yang dirancang untuk mentransformasikan data ke dalam informasi yang berguna”.

Informasi merupakan suatu proses yang dilakukan untuk mengubah data menjadi suatu informasi yang berguna, dimana informasi ini dapat digunakan untuk berbagai macam kebutuhan dari pemilik informasi. Salah satu contohnya adalah untuk mengambil keputusan. Informasi yang baik harus memiliki ciri-ciri seperti akurat, tepat waktu, dan relevan [5].

\section{Model Pengembangan Perangkat Lunak}

Software Engineering atau Rekayasa Perangkat Lunak adalah [6] "Aplikasi dari sebuah pendekatan disiplin dan sistematis kepada pengembangan perangkat lunak dan pemeliharaan 
INTENSIF, Vol.2 No.2 August 2018

ISSN: 2580-409X (Print) / 2549-6824 (Online)

Website: http//ojs.unpkediri.ac.id/index.php/intensif

dari perangkat lunak tersebut”. Pengertian Software Engineering menurut Elvis C Foster [7] "Proses dimana dilakukan proses observasi, perencanaan, pembuatan model, pengembangan, implementasi dan proses pemeliharaan. Software Engineering juga termasuk proses reengineering dari sistem yang sudah ada. Proses ini bertujuan untuk meningkatkan fung si dan performance dari sistem tersebut “. Software Engineering memiliki berbagai macam model seperti Waterfall Model, Spiral Model, Prototyping, Incremental, Open Source, Agile Method and Extreme Programming.

Model Waterfall merupakan salah satu model pengembangan perangkat lunak. Model Waterfall ini memiliki beberapa tingkatan seperti yang ditunjukkan pada gambar 2.

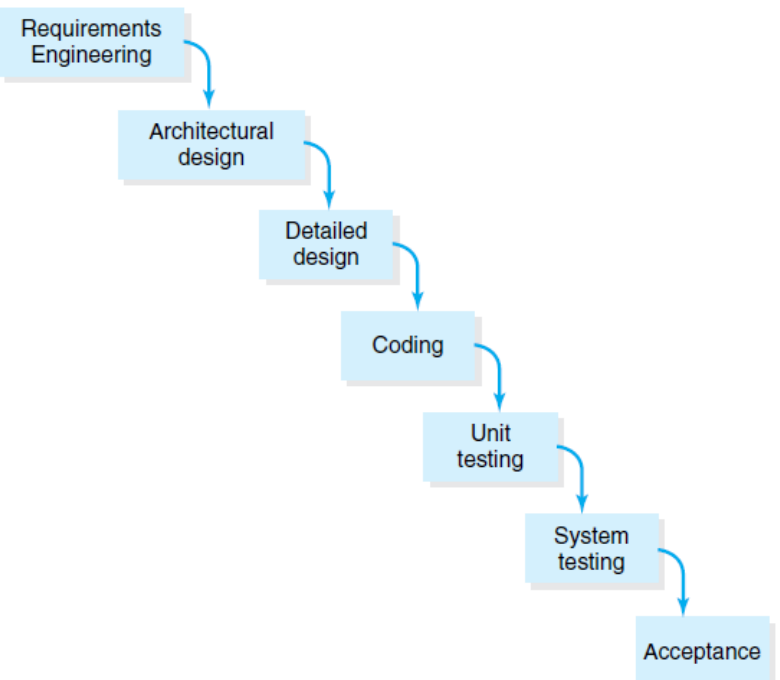

Gambar 2. MODEL WATERFALL

Model Waterfall memiliki 7 tingkatan, yaitu Requirement Engineering, Architectural Design, Detailed Design, Coding, Unit Testing, System Testing, dan Acceptance.

Requirement Engineering merupakan tahap pengumpulan data yang diperlukan dalam pembuatan sistem. Pada tahap ini biasanya dilakukan interview atau observasi terhadap pengguna. Output data dari tahap ini dapat digunakan pada tahap Architectural Design dan Detailed Design.

Architectural Design merupakan tahap pembuatan arsitektur desain keseluruhan sistem. Pada tahap ini akan dihasilkan gambar dari arsitektur desain sistem.

Tahap Detailed Design adalah tahap pembuatan desain dari User Interface (UI) sistem. Pada tahap ini akan dihasilkan User Interface yang dapat dipakai oleh pengguna sistem untuk berinteraksi dengan sistem. Tahap detailed design juga dapat disebut sebagai front end sistem.

Tahap coding adalah tahap pembuatan coding untuk desain User Interface yang telah dibuat pada tahap sebelumnya. Tahap ini juga disebut sebagai implementasi back end. 
Tahap unit testing merupakan tahap testing terhadap coding yang dibuat. Pada tahap ini testing dilakukan dengan tujuan supaya source code yang dihasilkan dapat berjalan sempurna sesuai dengan kebutuhan dari user dan bebas dari bug. System Testing merupakan tahap pengetesan yang dilakukan terhadap sistem secara keseluruhan. Pada tahap ini akan diadakan output apa saja kekurangan dari sistem yang dibuat, dan apabila terdapat error, maka akan dilakukan perbaikan.

Tahap terakhir adalah tahap acceptance. Pada tahap ini user menerima sistem yang telah dibuat.

\section{Unified Modeling Language (UML)}

UML memiliki kepanjangan Unified Modeling Language. UML menurut Chonoles dan J.A Schardt [8] merupakan "suatu metode yang terdiri dari berbagai macam diagram yang dapat digunakan untuk membantu programmer dan sistem analist untuk melakukan kegiatan spesifikasi, visualisasi, design arsitektur, pembuatan sistem, simulasi dan dokumentasi”.

Use Case Diagram merupakan salah satu diagram yang terdapat pada UML. Use Case Diagram digunakan untuk mendokumentasikan kebutuhan-kebutuhan yang terdapat pada sistem [9] . Terdapat 3 jenis simbol yang terdapat pada Use Case Diagram seperti yang ditunjukkan pada gambar 3 dibawah ini.

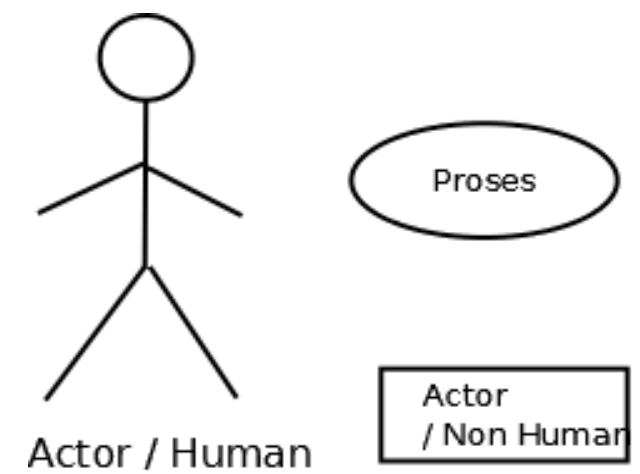

Gambar 3. Simbol Use CASE DiAgRAM

Class Diagram merupakan salah satu diagram yang juga terdapat pada UML. Class diagram digunakan untuk menggambarkan relasi-relasi yang terdapat pada setiap komponen-komponen class yang terdapat pada sistem [10].

\section{METODE PENELITIAN}

Desain aplikasi perangkat lunak berbasiskan web ini dikembangkan melalui metode Waterfall dengan tahapan analisa kebutuhan, desain, implementasi, dan uji coba serta perawatan 
INTENSIF, Vol.2 No.2 August 2018

ISSN: 2580-409X (Print) / 2549-6824 (Online)

Website: http//ojs.unpkediri.ac.id/index.php/intens if

sistem. Aplikasi ini dibangun dengan menggunakan software kombinasi AMP (Apache/MySQL/PHP) yang dioperasikan dengan sistem operasi Linux. Untuk mewujudkan perangkat tersebut dilakukan tahap perencanaan penelitian secara menyeluruh sesuai dengan tujuan yang ingin dicapai untuk setiap aktifitasnya seperti yang ditunjukkan pada gambar 4 berikut ini.

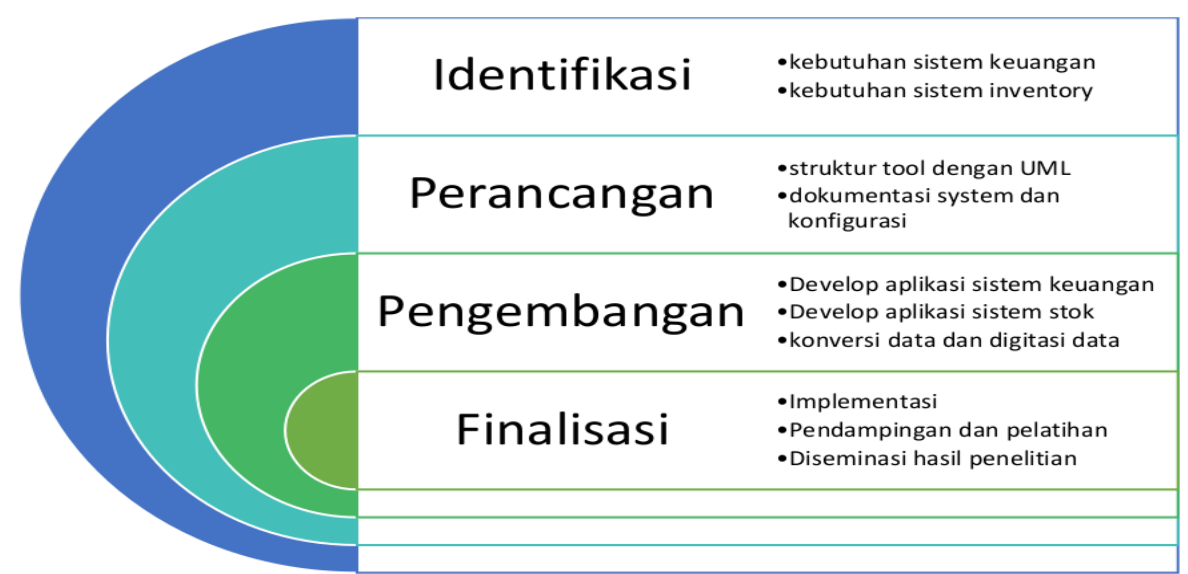

Gambar 4. RenCANa Aktivitas Pengembangan Penelitian

Pada gambar 4 dapat dilihat pada dasarnya penelitian ini mencoba mengali dengan mengembangkan sistem keuangan dan inventory atau sistem stok barang yang diterapkan pada UD Pawon Kue. Tahap perencanaan melakukan idenfikasi dan perencanaan dengan permodelan $U M L$, kemudian dalam setiap aktifitasnya mitra juga diajak untuk terus berdialog dan berdiskusi tentang apa saja yang menjadi kebutuhannya. Langkah berikutnya menggunakan tools berupa dokumen $U M L$ untuk menentukan setiap aktifitas yang dilakukan.

\section{ANALISA KEBUTUHAN PENELITIAN}

Untuk analisa kebutuhan dari penelitian ini dapat dijabarkan secara ringkas menggunakan fishbone diagram seperti yang ditunjukkan pada gambar 5 dibawah ini. Seperti yang ditunjukkan pada gambar fishbone dibawah ini bahwa salah satu permasalahan yang dihadapi oleh UD Pawon Kue adalah kelemahan pada stok dan keuangan yang diakibatkan oleh penggunaan sistem yang manual, sedangkan salah satu target output dari penelitian ini adalah menghasilkan suatu sistem yang mampu mengatasi kelemahan yang disebabkan oleh sistem manual yang dipakai oleh UD Pawon Kue. 
INTENSIF, Vol.2 No.2 August 2018

ISSN: 2580-409X (Print) / 2549-6824 (Online)

Website: http://ojs.unpkediri.ac.id/index.php/intensif

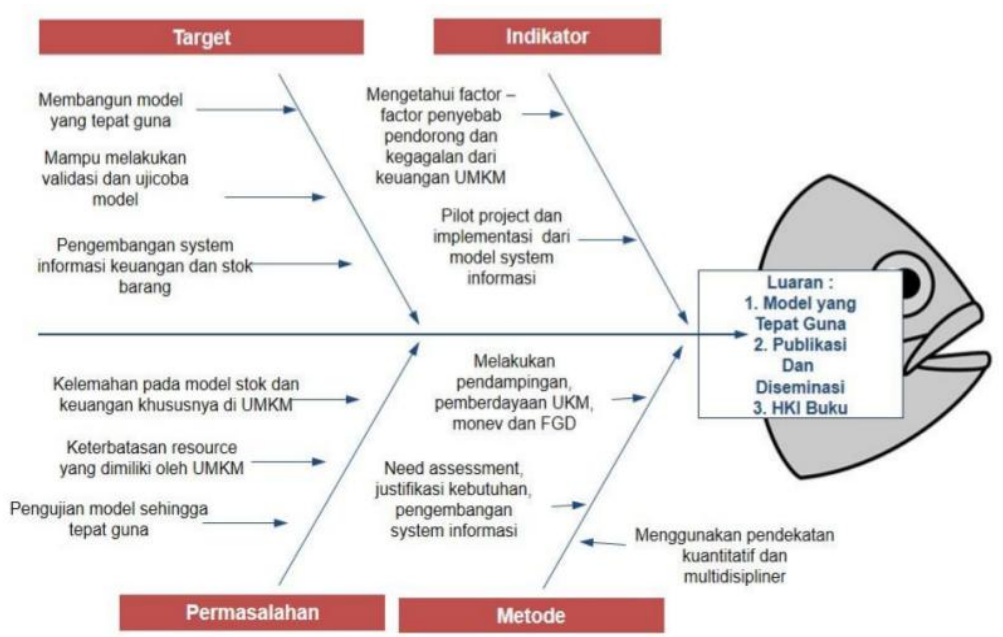

Gambar 5. FISHBONE DIAGRAM PENELITIAN

\section{HASIL DAN PEMBAHASAN}

Seperti yang telah dijelaskan pada metode penelitian, bahwa model pengembangan perangkat lunak yang dipakai adalah model Waterfall. Berikut ini hasil yang dicapai pada setiap tahap yang terdapat pada metode Waterfall.

Tahap requirements engineering merupakan tahap pengumpulan data kebutuhan dari user. Pada tahap dilakukan survey dan wawancara mengenai apa saja kebutuhan user terhadap aplikasi yang akan dibangun. Pada tahap ini didapatkan bahwa user membutuhkan suatu aplikasi yang dapat membantu dalam penjualan dan pencatatan stok. Gambar 6 menunjukkan penulis dan team yang melakukan proses wawancara dan dokumentasi pada UD Pawon Kue.

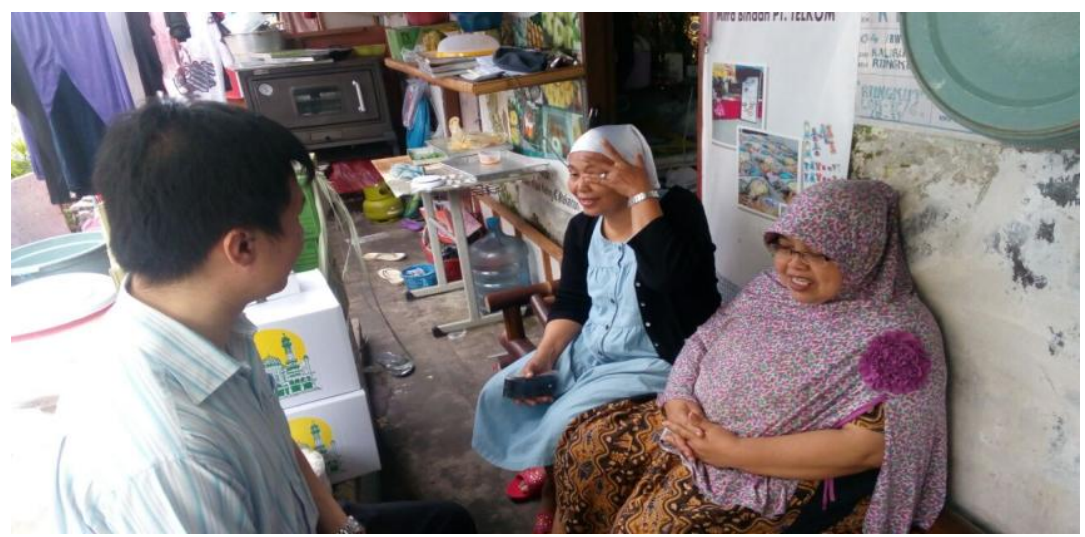

Gambar 6. PROSES WAWANCARA TERHADAP USER

Tahap architectural design dibuat desain sistem secara keseluruhan. Desain sistem secara dapat dilihat pada gambar 7. Pada gambar 7 dapat dilihat bahwa aplikasi yang dibuat ini dapat diakses dengan menggunakan smartphone dan komputer. Tujuan dibuatnya aplikasi ini 
INTENSIF, Vol.2 No.2 August 2018

ISSN: 2580-409X (Print) / 2549-6824 (Online)

Website: http//ojs.unpkediri.ac.id/index.php/intensif

menggunakan teknologi web adalah untuk memudahkan pemilik UD Pawon Kue dalam mengakses sistem.

Terdapat tiga output pada tahap detailed design pada penelitian ini. Output pertama adalah Use Case diagram yang dipakai untuk menggambarkan service-service apa saja yang dapat direquest oleh user. Output pertama ini dapat dilihat pada gambar 8 dan gambar 9. Output kedua merupakan gambar class diagram dari aplikasi yang akan dibuat. Output kedua dapat dilihat pada gambar 10. Output ketiga merupakan output dari design user interface yang dibuat pada aplikasi ini. Terdapat dua jenis user interface pada aplikasi ini, yaitu user interface untuk administrator yang ditunjukkan pada gambar 11 dan user interface untuk pembeli yang ditunjukkan pada gambar 12.

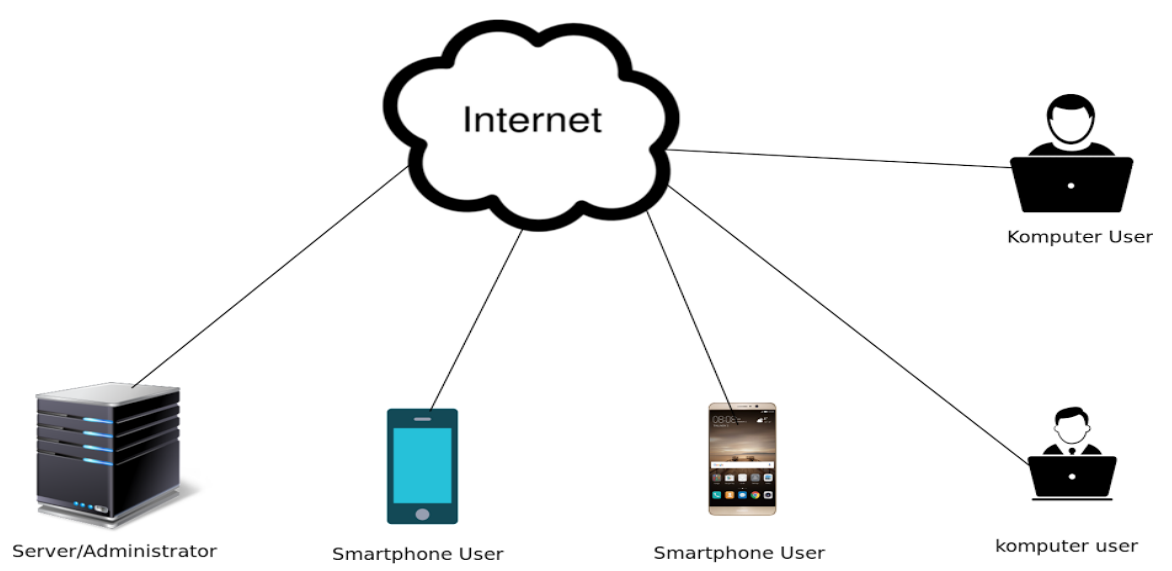

Gambar 7. ARSITEKTUR SISTEM UD PAWON KUE

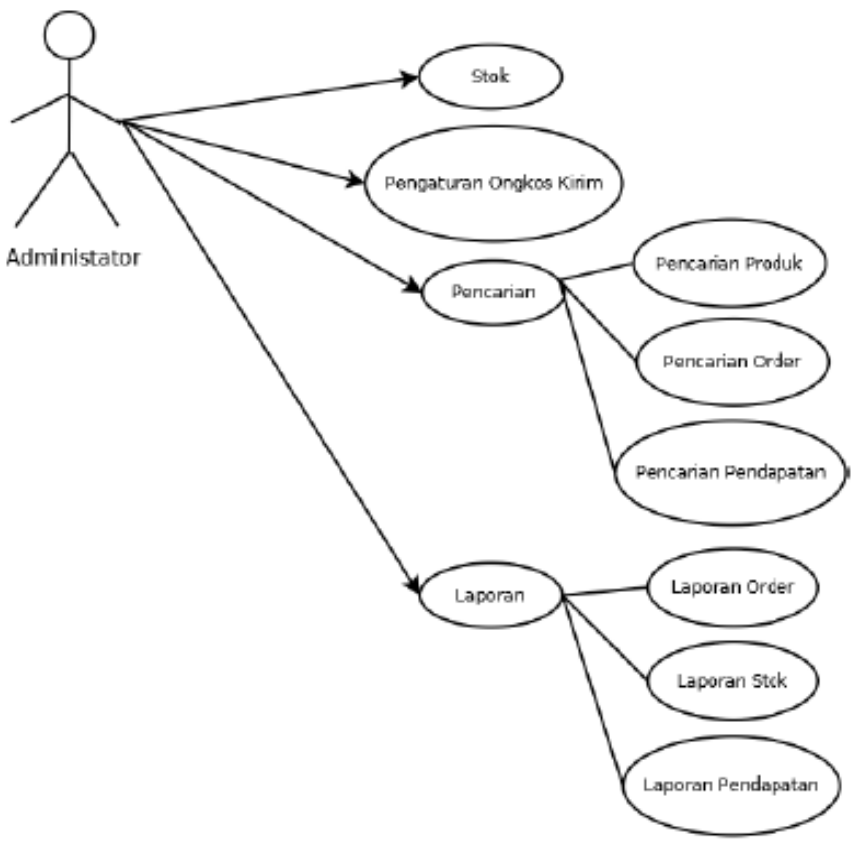

Gambar 8. USE CASE DIAGRAM ADMINISTATOR 
INTENSIF, Vol. 2 No. 2 August 2018

ISSN: 2580-409X (Print) / 2549-6824 (Online)

Website: http://ojs.unpkediri.ac.id/index.php/intens if

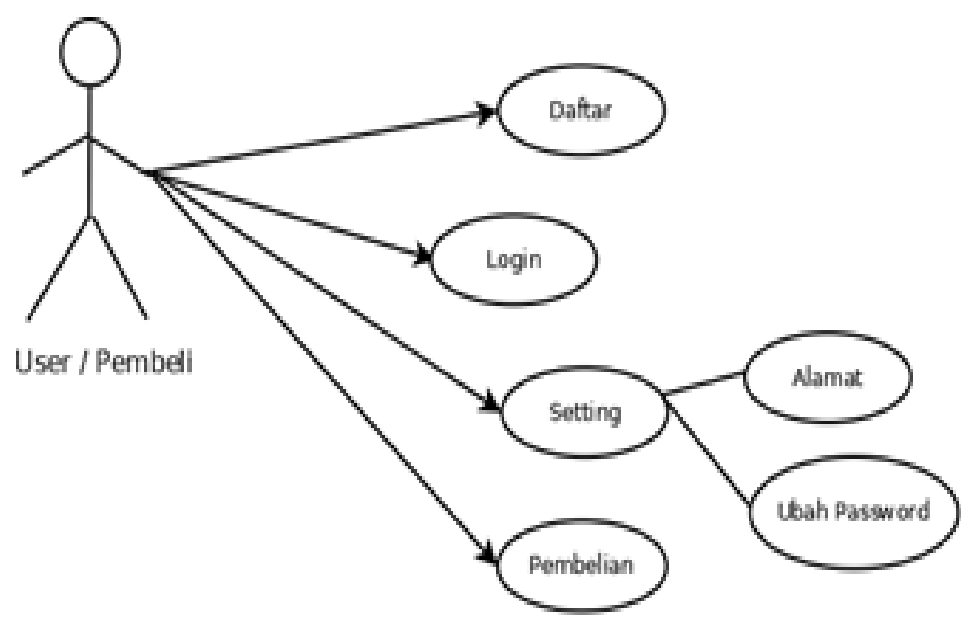

Gambar 9. USE CASE DIAGRAM PEMBELI

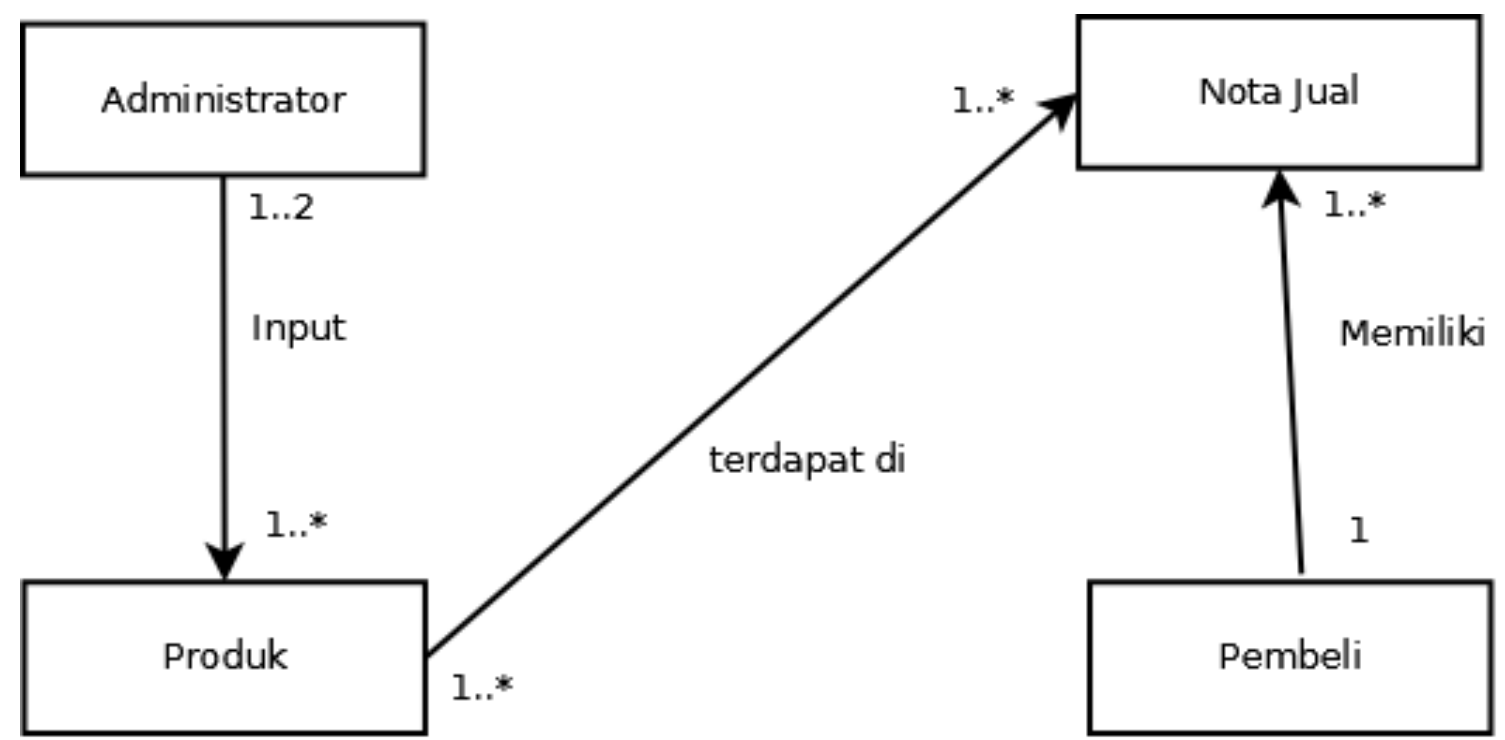

Gambar 10. CLASS DIAGRAM APLIKASI UNTUK UD PAWON KUE 
INTENSIF, Vol.2 No.2 August 2018

ISSN: 2580-409X (Print) / 2549-6824 (Online)

Website: http//ojs.unpkediri.ac.id/index.php/intensif

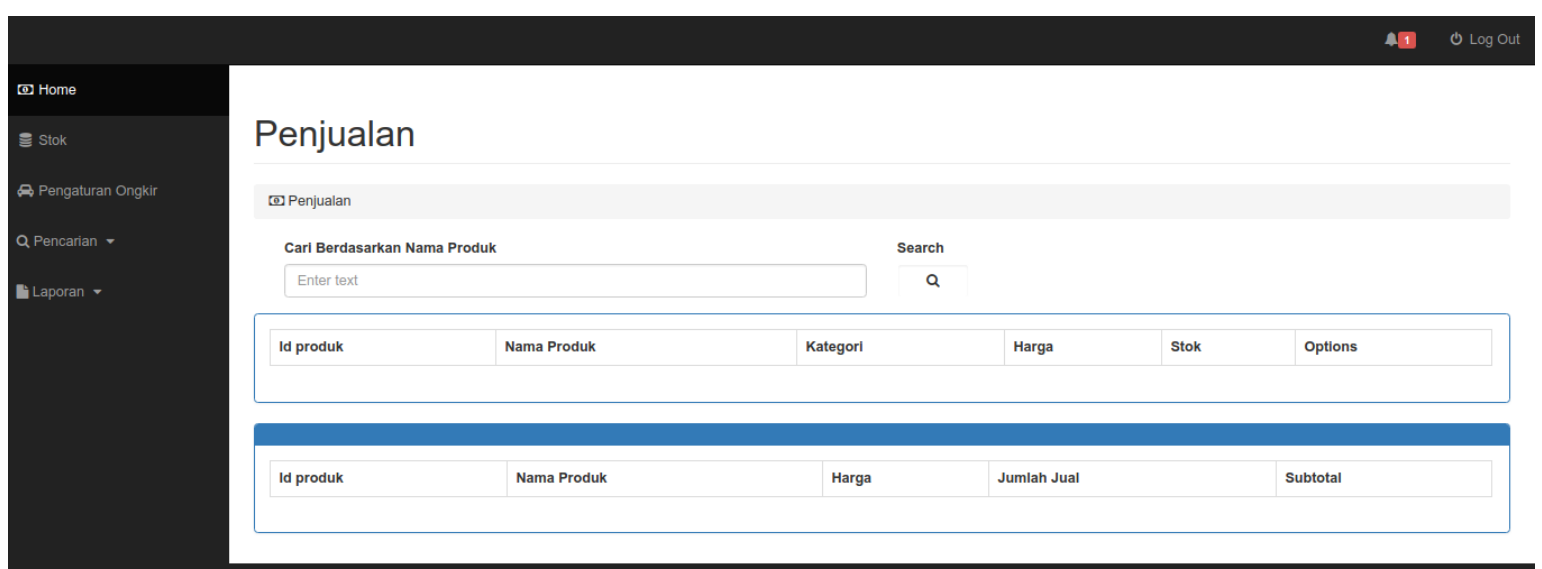

Gambar 11. DESAIN USER INTERFACE ADMINISTRATOR
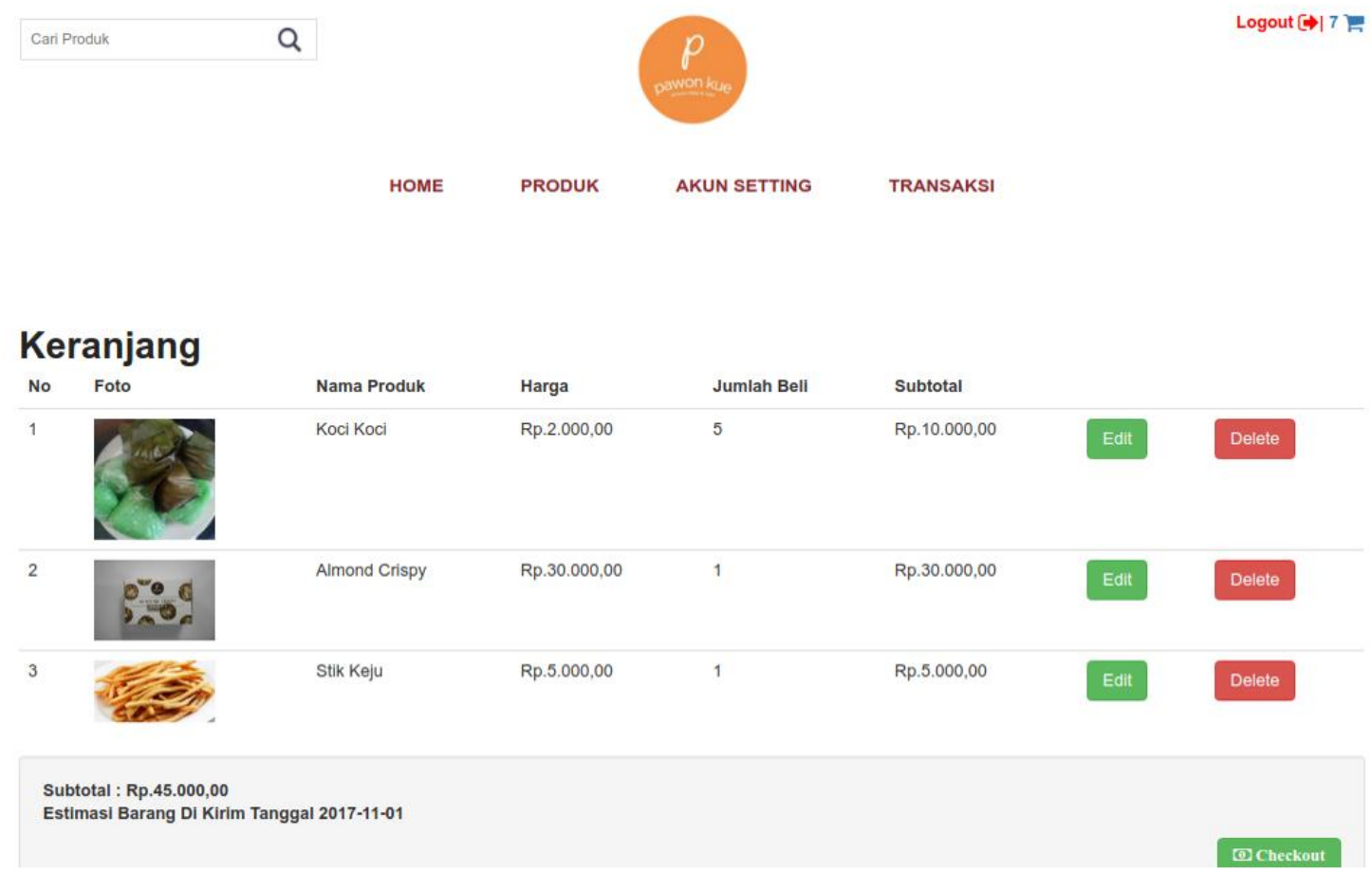

Gambar 12. DESAIN USER INTERFACE CUSTOMER

Tahap testing dilakukan pada system yang telah dibuat. Testing dilakukan dengan menggunakan metode Black Box. Tabel 1 merupakan tabel yang berisi pengujian yang dilakukan pada form administrator. Tabel 2 merupakan tabel yang berisi uji coba yang dilakukan pada form input data stok. 
INTENSIF, Vol.2 No.2 August 2018

ISSN: 2580-409X (Print) / 2549-6824 (Online)

Website: http://ojs.unpkediri.ac.id/index.php/intensif

Tabel 1. UJI COBA FORM ADMINISTRATOR

\begin{tabular}{llllll}
\hline \hline No & Skenario & \multicolumn{2}{l}{$\begin{array}{l}\text { Hasil } \\
\text { diharapkan }\end{array}$} & yang & Hasil sesungguhnya \\
\hline 1. & $\begin{array}{l}\text { Memasukkan user name dan password } \\
\text { yang benar pada form login } \\
\text { administrator }\end{array}$ & $\begin{array}{l}\text { User masuk ke } \\
\text { halaman menu untuk } \\
\text { administrator }\end{array}$ & $\begin{array}{l}\text { User masuk ke } \\
\text { halaman menu untuk } \\
\text { administrator }\end{array}$ \\
\hline Memasukkan data yang tidak valid & Muncul pesan error & Muncul \\
pada form login administrator & & & & \\
\hline
\end{tabular}

Tabel 2. UJI COBA FORM INPUT STOK BARU

\begin{tabular}{llll}
\hline \hline No & Skenario & $\begin{array}{l}\text { Hasil yang } \\
\text { diharapkan }\end{array}$ & Hasil sesungguhnya \\
\hline 1. & $\begin{array}{l}\text { Memasukkan semua data pada form } \\
\text { Input Stok Baru dan menekan tombol } \\
\text { simpan }\end{array}$ & $\begin{array}{l}\text { Sistem menyimpan } \\
\text { data ke database dan } \\
\text { menampilkan pesan } \\
\text { bahwa data berhasil } \\
\text { disimpan }\end{array}$ & $\begin{array}{l}\text { Sistem menyimpan } \\
\text { menampilkan pesan } \\
\text { bahwa data berhasil } \\
\text { disimpan }\end{array}$ \\
\hline 2. & $\begin{array}{l}\text { Sistem menyimpan data ke database } \\
\text { dan menampilkan pesan bahwa data } \\
\text { berhasil disimpan }\end{array}$ & $\begin{array}{l}\text { Sistem menampilkan } \\
\text { pesan error }\end{array}$ & $\begin{array}{l}\text { Sistem menampilkan } \\
\text { pesan error }\end{array}$ \\
\hline
\end{tabular}

Tahap berikutnya adalah melakukan uji coba testing secara keseluruhan. Pada tahap ini user diberikan kesempatan dalam melakukan uji coba sistem yang sudah dibuat. Pada tahap ini user juga dimintai pendapatnya mengenai sistem yang telah dibuat. Secara keseluruhan UD Pawon Kue cukup puas dengan aplikasi yang sudah dibuat.

\section{KESIMPULAN DAN SARAN}

Pada tahap testing user juga dimintai pendapatnya mengenai sistem yang telah dibuat. Secara keseluruhan UD Pawon Kue cukup puas dengan aplikasi yang sudah dibuat. Program penjualan dan pencatatan stok yang dibuat oleh UD Pawon Kue cukup membantu UD Pawon Kue dalam melakukan pencatatan dan penjualan produk-produk yang dimiliki oleh UD Pawon Kue.

\section{UCAPAN TERIMAKASIH}

Secara khusus, tim PDP Program Studi Teknik Informatika Universitas Widya Kartika Surabaya mengucapkan banyak terima kasih untuk waktu dan tenaga yang diberikan oleh Ibu Choirul Mahpuduah beserta suami dan staff yang ikut membantu dalam penelitian ini. Semoga kerja sama ini dapat terus berjalan dan lebih meningkat lagi. Ucapan terima kasih juga diberikan kepada Ditjen Pendidikan Tinggi yang telah mendanai kegiatan ini. Tim juga mengucapkan terima kasih kepada Ketua LP3M Universitas Widya Kartika beserta para staffnya 
INTENSIF, Vol.2 No.2 August 2018

ISSN: 2580-409X (Print) / 2549-6824 (Online)

Website: http:/ojs.unpkediri.ac.id/index.php/intensif

\section{DAFTAR PUSTAKA}

[1] R. Firliana, D. Harini, and A. R. A, "Sistem Informasi Layanan Kredit UKM Berbasis SMS Gateway," Intensif, vol. 1, no. 1, pp. 53-62, 2017.

[2] J. Ouhadi, "A Qualitative Analysis of Factors Associated With User Acceptance and Rejection of A New Workplace Information System in The Public Sector," Can. J. Adm. Sci., vol. 10, pp. 201-203, 2008.

[3] Z. S. Wijaya, "Pada Aplikasi Monitoring Keuangan Dan Aset ( Terkait Penatausahaan Piutang Tuntutan Ganti Kerugian Negara ),” J. Ekon. Akutansi dan Manaj., vol. 14, no. 1, pp. 1-10, 2015.

[4] A. Kadir, Pengenalan Sistem Informasi Edisi Revisi. Yogyakarta: Andi Publisher, 2014.

[5] R. Pamungkas, "Perancangan Sistem Informasi Pembayaran Administrasi SMK Negeri 1 Jiwan," Intensif, vol. 1, no. 2, pp. 129-136, 2017.

[6] Y. A. Binarso, E. A. Sarwoko, and N. Bahtiar, "Pembangunan sistem informasi alumni berbasis web pada program studi teknik informatika universitas diponegoro," J. Inf. Technol., vol. 1, no. 1, pp. 72-84, 2012.

[7] E. C. Foster, Software Engineering A Methodical Approach. 1st Edition, 2014.

[8] M. J. J. A. S. Chonoles, UML 2 for Dummies. New York: Willey Publishing, 2003.

[9] N. Hidayati, "Penggunaan Rapid Application Development Dalam Rancang Bangun Program Simpan Pinjam Pada Koperasi,” vol. 2, no. 2, pp. 87-97, 2018.

[10] R. F. Antasari and Kusrini, "Perancangan Aplikasi Mobile Bengkelku Sebagai Informasi Alamat Bengkel Resmi Sepeda Motor Di Kota Yogyakarta Menggunakan Gps Berbasis Android," vol. 13, no. 4, pp. 38-42, 2012. 